NBER WORKING PAPER SERIES

\title{
ANNUITY VALUES IN DEFINED CONTRIBUTION RETIREMENT SYSTEMS: THE CASE OF SINGAPORE AND AUSTRALIA
}

\author{
Suzanne Doyle \\ Olivia S. Mitchell \\ John Piggott \\ Working Paper 8091 \\ http://www.nber.org/papers/w8091 \\ NATIONAL BUREAU OF ECONOMIC RESEARCH \\ 1050 Massachusetts Avenue \\ Cambridge, MA 02138 \\ January 2001
}

The authors are grateful for financial support to the Economic Research Institute, the Singapore Management University, the Australian Research Council, and the National Bureau of Economic Research, and to Matthew Williams for research assistance. Helpful comments were provided by Augustine Tan. This study is part of the NBER program on the Economics of Aging. The views expressed herein are those of the authors and not necessarily those of the National Bureau of Economic Research.

(C) 2001 by Suzanne Doyle, Olivia S. Mitchell, and John Piggott. All rights reserved. Short sections of text, not to exceed two paragraphs, may be quoted without explicit permission provided that full credit, including (C) notice, is given to the source. 
Annuity Values in Defined Contribution Retirement Systems: The Case of

Singapore and Australia

Suzanne Doyle, Olivia S. Mitchell, and John Piggott

NBER Working Paper No. 8091

January 2001

JEL No. G23, J14, J32, H32

\section{$\underline{\text { ABSTRACT }}$}

In this paper we derive and compare the value of life annuity products in an international context. Our specific goal is to assess the money's worth and adverse selection impact of annuities in two countries - Singapore and Australia - that have mandatory DC-type retirement plans. This similarity in plan type is offset by differences in the two countries' national retirement policies. Our comparison therefore exploits the natural experiment in annuity pricing and purchase behaviour under alternative retirement regimes. The results show that after controlling on administrative loadings, there appear to be important differences in measured adverse selection across countries. Specifically, selection appears to be far stronger in the presence of a generous public benefit scheme that provides a first line of defence against the risk of old-age poverty.

Suzanne Doyle

School of Economics

University of New South Wales

Sydney 2052, Australia

email: $\underline{\text { s.doyle@unsw.edu.au }}$
Olivia S. Mitchell

Professor of Insurance and Risk Management The Wharton School

3641 Locust Walk, Rm. 304 CPC

Philadelphia PA, 19104-6218

and NBER

email: mitchelo@wharton.upenn.edu

John Piggott

School of Economics

University of New South Wales

Sydney 2052, Australia

email: J.Piggott@unsw.edu.au 


\section{Annuity Values in Defined Contribution Retirement Systems: The Case of Singapore and Australia}

More older people are now looking ahead to their retirement years than ever before in world history. This global age wave has heightened awareness of the financial and mortality risks that confront retirees, risks that sometimes take people by surprise (Bodie 2000). Throughout much of the developed world, programs have been developed to provide a degree of social insurance against such risks. For example, public pension systems in many countries provide payments to the aged that help protect people against outliving their resources due to longevity risk and/or financial misfortune. Much the same motivation underlies the provision of defined benefit (DB)-type pension plans of the sort that until recently were the predominant form of private retirement provision in the Western world. These were typically configured to pay out a guaranteed retirement income stream linked to worklife earnings and that continued until death (McGill et al., 1996). Often survivorship benefits were also available under these plans.

In both sorts of defined benefit arrangement, risks are pooled across stakeholders taxpayers, employees, and employers - and over time, to spread them cross-sectionally and intertemporally. By contrast, a rather different pattern of risk-bearing is taking shape as many countries adopt or enhance already-existing accumulation-based or defined contribution (DC) retirement systems. Either publicly-mandated or voluntarily provided, the DC model is characterized by specifying the contribution that must be made to the plan, usually as a fraction of employee earnings. This model has been adopted in several Asian countries via mandatory saving plans, systems that require workers and/or their employers to contribute a given fraction of earnings into a pension plan. Under many DC-type plans, there is typically little if any risk- 
spreading between the plan stakeholders. That is, participants have their own individual accounts, and the sponsor's obligation typically ceases with the termination of labor services at retirement.

The DC-type pension plan has become a powerful engine for channelling workers' earnings to retirement-saving purposes. These kinds of plans have also become an important source of retirement finance the world over (Palacios and Pallares-Miralles, 2000). Yet in the rush to design effective DC accumulation vehicles, there has thus far been too little attention paid to how the plans will function during the decumulation phase. The specific problem that many of these plans therefore confront is that retirement asset accumulations must be managed carefully beyond the retirement date all the way to death, so as to ensure a dependable flow of income in retirement.

Economic analysis has previously demonstrated that products such as life annuities can play a key role in this process, working to ensure a degree of consumption smoothing through time. ${ }^{1}$ Despite their theoretical attractiveness, empirical evidence from the US and the UK finds that few people hold annuities in their retirement portfolios and voluntary annuity markets remain thin. Reasons for this small demand to date are not well understood, but several possible explanations come to mind. First, older people may not convert all their assets to annuities because they plan on bequeathing some of the funds to their heirs. Second, older people may avoid annuities believing they need to hold precautionary balances to cope with uninsurable events. Third, older people in some countries already hold much of their wealth in annuitized form, due to publicly-provided social security lifetime benefits. As a result, they may not feel the need to avail themselves of additional voluntary annuities.

\footnotetext{
${ }^{1}$ See for instance Friedman and Warshawsky (1988, 1990), Warshawsky (1988), Brown et al. (2000) and Mitchell et al. (1999).
} 
In the past, some evidence suggested that life annuity prices were rather high relative to population life expectancy and to alternative investment returns, but of late prices have been dropping steadily, at least in the US (Brown et al., forthcoming). Less well understood is the relationship between annuity prices and annuity returns in other countries, and this is the subject of our analysis below.

In what follows we first briefly review the retirement policy frameworks in Australia and Singapore. This comparison requires the calculation of annuity "money's worth," or the ratio of the expected present discounted value (EPDV) of an annuity to its purchase price. This provides an index of how good a deal an annuity offer is. We compare the money's worth of individual annuities offered in Singapore and Australia, since both countries rely on a mandatory DC-type plan as their primary employment-linked compulsory retirement vehicle. However the two countries have sharply contrasting annuity markets and social welfare systems, as we shall show. Next we lay out the assumptions and methods used to calculate money's worth of lifetime annuities. Results follow, along with a brief discussion of their potential relevance to other countries.

\section{The Retirement Framework in Singapore and Australia}

Singapore and Australia were deliberately chosen for this study because both rely on mandated contributions to national DC systems, rather than on pay-as-you-go taxes to finance an employment-related retirement benefit program. ${ }^{2}$ In Singapore, the Central Provident Fund (CPF) operates as a centrally-administered publicly-mandated retirement scheme built around individual accounts. Both employees and employers must contribute a substantial fraction of

\footnotetext{
${ }^{2}$ Throughout, domestic currencies are used for dollar values. As at July 2000, \$US $1=\$$ Aus 1.76; and \$US $1=$ $\$$ Sg 1.8 .
} 
earnings until the employee attains age 55. The current contribution rate is set at 32 percent, split between employers and employees, though the rate was 40 percent until the Asian crisis. ${ }^{3}$ Fund accumulations are used partly to provide a buffer to cover participant healthcare expenses (6 percent) and they may also be used for the (heavily subsidized) purchase of residential property. They may sometimes be used for small business investment and education. Other than the CPF, the Central Government provides limited financial support for the aged. Fewer than 2 percent of the elderly receive social assistance from the government, and an emphasis is placed on family provision for the elderly. In addition, labour force participation among the elderly is high by developed-economy standards. ${ }^{4}$

In Australia, by contrast, a relatively generous and means-tested social safety net insulates the elderly from destitution. ${ }^{5}$ By law, the minimum-income safety net is targeted so the monthly indexed pension for life amounts to 25 percent of average male full-time earnings for a single pensioner, and 40 percent for a couple. This social insurance payment, along with the owner-occupied housing paid for over workers' lifetimes, is the major source of retirement finance for most elderly Australians. The minimum benefit is means-tested against both income and assets, but the thresholds are set relatively high: over half the aged in Australia currently receive a full government old-age benefit, and 75 percent receive some payment from this safety net program.

In addition to the safety-net benefit, Australia has mandated a privately-managed defined contribution system termed the "Superannuation Guarantee" system. Under these rules, employers must pay 9 percent of earnings (phased in through 2002) to a pension fund, with the fund manager selected by the employer. Participating employees have some freedom over

\footnotetext{
${ }^{3}$ It is anticipated that the contribution rate will return to the 40 percent level in the future.

${ }^{4}$ For more detail on the Singaporean pension system see www.cpf.gov.sg and Asher (1999).
} 
portfolio choice, subject to offerings provided by their fund manager. ${ }^{6}$ The retirement accumulation is required to be "preserved" - that is, not used by the worker for virtually any reason - until the age of 55. (This latter age is being increased to 60 over time). Thus far, accumulations have been well-insulated against uses for housing or education.

\section{Retirement Payouts in Singapore}

Singapore's CPF design, with mandatory contributions of up to 40 percent, might lead one to conclude that Singaporean workers would reach retirement age having accumulated large holdings in their DC portfolios. Nevertheless this entire accumulation does not need to be preserved in the fund to retirement age. The bulk of the funds is actually used for investment in housing. As a result, retirement accumulations in the $\mathrm{CPF}$ financial portfolio are generally low.

This outcome prompted a policy change in the early 1990s such that authorities began to require retirees to have what is termed a "minimum sum" at retirement - one that must be accumulated by age 55 . The minimum sum is a lower-bound financial asset target that by law must now be preserved for a further 7 years until age 62. The minimum sum was set at $\$ \mathrm{Sg}$ 65,000 in the year 2000 , rising to $\$ S g 80,000$ by the year 2003 . Currently only a minority of retirees has accumulated enough assets to meet the minimum sum requirement by age 55 in financial assets, with most having to "pledge their dwelling equity" to make up the shortfall. Financial accumulations up to the minimum sum cannot generally be taken as a lump sum at retirement. When the funds become accessible at age 62, they must either be left in the CPF to earn interest, be deposited in an approved bank for gradual and regulated drawdown, or be used to purchase a life annuity.

\footnotetext{
${ }^{5}$ For more on the Australian retirement system see Bateman, Kingston and Piggott (forthcoming)

${ }^{6}$ Legislative initiatives are pending to free up this restriction.
} 
The effect of this CPF regulatory evolution has been to boost the size of the annuity market in Singapore substantially. Table 1 indicates the number and value of annuities sold each year over the last decade. Except for a decline during the Asian crisis, annuity sales have shown a steady increase over this period. In 1999, for instance, about one-sixth of the retiring workforce purchased an annuity, a rather large penetration rate compared to other countries. This represented the sale of 3,200 annuities for an aggregate premium value of \$Sg 173 million, out of about 22,000 new retirees that year.

\section{Table 1 here}

There are several annuity issuers in Singapore offering products that differ in detail but are similar in broad structure. The preservation requirement means that all annuities offered are deferred for 7 years; after that, they typically have a guarantee period or repayment sum, which extends for some other number of years. Some annuities are offered with escalation of 1 or 2 percent a year or with a discretionary profits add-on. One frequently-offered option is to purchase a nominal life annuity with a 7-year deferral period and also a further 15-year guarantee period. This is equivalent to purchasing a 15-year term annuity that is deferred for 7 years, along with a life annuity promising the same monthly payment deferred for 22 years. We have chosen this as our exemplar in the money's worth calculations reported below.

\section{Retirement Payouts in Australia}

Payouts from employer-sponsored pension (Superannuation) plans in Australia are relatively lightly regulated. Benefits may be taken as a lump sum up to generous limits, and about 75 percent of payouts are currently in this form. ${ }^{7}$ By contrast with Singapore, the Australian retirement income stream market is relatively small, comprising a diverse array of

\footnotetext{
${ }^{7}$ These payouts are frequently invested after being withdrawn, but no reliable data exist on their exact disposition.
} 
investment and retirement provision products. Available arrangements may be classified into three major product groupings: lifetime annuities, term certain annuities, and phased withdrawals which are termed "allocated annuities and pensions" in Australia. Both life and term annuities have been available in the Australian market for many years, while the allocated products have only been on offer since late 1992. A snapshot of this market indicates that allocated annuities and pensions attract the largest proportion of income stream capital, representing over 70 percent of total funds under management in July 2000. On the other hand, the combination of term and life annuities represents only 29 percent of the funds under management in Australia (see Figure 1).

\section{Figure 1 here}

Allocated products have characteristics quite different from other income stream products. In particular, the investment risk of retirement capital is entirely borne by the annuitant, and as such they can choose from an array of investment options. Of the total funds under management in allocated products, 63 percent are with managed funds, 23 percent in capital stable and 14 percent with the money market (Plan for Life Research 2000b). These products can only be purchased with specific retirement saving money, and the annual income drawdowns can vary between an upper and lower threshold. These characteristics have made allocated products very popular with Australian retirees, which is evident by the growth experienced since the early $1990 \mathrm{~s}^{8}$

On the other hand, life and term annuities protect annuitants against rate of return risk. Payouts may be fixed in nominal terms, indexed to inflation (the CPI), or escalated at a fixed rate. A guarantee period can be nominated at the time of purchase, where payments continue to

\footnotetext{
${ }^{8}$ Since their introduction, funds under management have increased from around \$Aust 3 billion to more than \$Aust 25 billion in June 2000 (Plan for Life Research 2000b).
} 
be paid for a minimum period even if the annuitant dies during this time. These annuities can be bought with funds from any source.

A term annuity may also be specified to pay back a percentage of the original capital on expiry of the contract — a residual capital value (RCV). Many of the short-term annuities specify an income of interest only and 100 percent return of capital at the end of the contract, while many of the longer-term annuities specify an income comprising both interest and capital. Short-term annuities are the most popular form of immediate annuity offered in Australia, relative to genuine longevity annuities (life and life expectancy products). ${ }^{9}$ As seen in Figure 2 , the recent incentive structure implemented in 1998 designed to encourage longevity annuities has not resulted in a large swing towards these types of income stream products. ${ }^{10}$

Figure 2 here

Available trade data suggest that very few people in the retiring population buy genuine longevity annuities at retirement. In June 2000, there were 125,849 immediate annuity policies in force in Australia, of which one-quarter were life annuities and three-quarters were term annuities. ${ }^{11}$ New sales are also highly skewed toward the term policy: for example in 1999, of 33,001 immediate annuity policies sold (worth \$A 2.75 billion), approximately 3,000 were life annuities and 10,000 term annuities with no RCV. Based on Australian Treasury data, only 3 percent of the estimated 100,000 Australians retiring each year purchased a life annuity. ${ }^{12}$ Turning to allocated annuities and pensions, though they are sold by different entities, they are

\footnotetext{
${ }^{9}$ Short-term annuities are an attractive and tax-preferred means of preserving superannuation accumulations between preservation age and actual retirement.

${ }^{10}$ Longevity annuities meeting certain criteria are income and asset test exempt under eligibility criteria for the Age Pension.

${ }^{11}$ The average annual income paid out under the life annuity contract was $\$ A 6,536$, and $\$ A$ 8,565 for a term annuity (Plan for Life Research 2000a).

${ }^{12}$ A life annuity can be purchased at any time by a retiree, not just at their initial retirement date. The retiree estimates are based on unpublished Treasury data on workers over 55 withdrawing from the labour force.
} 
similar products. Allocated annuities are formally defined as life insurance products and are sold only by registered Life Offices; by contrast, allocated pensions may be sold by non-Life Offices including Public Superannuation Trustees. In June 2000 the stock of recipients stood at some 244,000 people receiving allocated annuities/pensions, with only 58,000 receiving annuity benefits $^{13}$ (Plan for Life Research 2000b).

\section{Calculating Annuity Money's Worth}

An annuity promise represents a stream of income payments over a future period, with the payout duration a specified term or contingent on a specified event (e., g. an individual's survival). This latter contract is the simplest form of a life annuity. Annuitants typically pay a lump sum (or single premium) to an annuity provider in return for the promised stream of payments. In a competitive market without commercial costs, the equivalence principle implies that the expected present discounted value (EPDV) of the benefit stream measured over the covered population should equal the original aggregate amount paid for the annuity. Simple equivalence is unlikely to hold in practice, of course, because there are costs that annuity providers have to cover including commissions, administration and marketing costs, reserves, and taxes.

The divergence between the initial premium and the EPDV of an annuity has been termed a "loading" by various authors including Friedman and Warshawsky $(1988,1990)$ and Mitchell et al., (2000). The EPDV of \$1 in premium used to purchase an annuity is the money's worth of the annuity, and the difference between the initial \$1 premium and the EPDV of the

\footnotetext{
${ }^{13}$ Of this, approximately 58,000 accounts were annuity contracts with Life Offices, receiving \$Aust 423.3 million pa.
} 
annuity represents the proportion of the premium that the annuitant is giving up in order to obtain longevity insurance.

On voluntary life annuities, the EPDV is calculated with population mortality tables, and here the loadings can be substantial. Ten years ago, voluntary private annuity markets in the US, for instance, had total loadings on a nominal individual annuity worth almost 20 cents per dollar of premium for a 65 year old male, and 15 cents for a 65 year old female (Mitchell et al., 2000). These loadings have come down substantially in recent years (Brown et al., 2000). Such loadings reflect not only commercial costs but also adverse selection.

Annuity issuers use annuitant mortality tables to factor in the lighter mortality of voluntary annuity purchasers. The loadings on an annuity are smaller when valued using an annuitant mortality table - on this calculation, the loading reflects only commercial costs. The difference between the EPDV of an annuity calculated using population versus annuitant mortality tables reflects the extent of adverse selection. The existence of adverse selection in the US voluntary annuity market is documented by Brown et al., (2000), Mitchell et al.,(2000), and Friedman and Warshawsky $(1988,1990)$. To a limited extent, it is also present in the UK. ${ }^{14}$ One interesting finding thus far is that in the US, nearly half of the disparity between the expected discounted value of the payouts and the policy premium appears to be due to adverse selection. In the UK, adverse selection also accounts around half of the total loading on voluntary annuities (Finkelstein and Poterba, 1999).

\section{Defining Annuities Money's Worth Values}

\footnotetext{
${ }^{14}$ See Finkelstein and Poterba (1999) and Murthi et al. (1999). Work in progress by James and Vittas (1999) explores a similar question in a range of other countries.
} 
An annuity's money's worth is the ratio of the EPDV of annuity payments to the initial premium paid. The EPDV for a nominal annuity with a guarantee period is calculated according to:

$$
\operatorname{EPDV}(\text { nominal })=\frac{\sum_{t=1}^{N \times 12} \frac{A_{x}}{(1+r)^{t}}+\sum_{t=(N \times 12)+1}^{(\omega-x) \times 12} \frac{A_{x} \times_{t} p_{x}}{(1+r)^{t}}}{K}
$$

where $\mathrm{N}$ is the guarantee period, set at 15 years; $\mathrm{x}$ is the age at which the annuity is purchased, assumed to be 55; $\mathrm{r}$ is the monthly riskless nominal interest rate; $\omega$ is the maximum life span, assumed to be 99 years of age; $A_{x}$ is the monthly annuity rate at the age of purchase; ${ }_{t} p_{x}$ is the probability that the individual age $\mathrm{x}$ will be alive after $\mathrm{t}$ months; and $\mathrm{K}$ is the premium used to purchase the annuity at age 62 (assumed to be $\$ 65,000$ compounded at 5 percent per annum for the term of the deferral).

There are three important variable inputs to the EPDV calculation: the annuity market quote, the interest rate used to discount the annual payment, and the mortality table used to determine how quickly to pay out the asset base over time. Data on the annual annuity payments and expected interest rates are drawn from market information, and for the purposes of money's worth calculations, are fairly straightforward to obtain.

Mortality estimates are more difficult to come by, and our approach requires some elaboration. To calculate the money's worth of market annuities and the extent of adverse selection, mortality estimates are needed for the general population and for annuitants. ${ }^{15}$ These must be developed on a cohort basis and appropriately dated to match annuity pricing. ${ }^{16} \mathrm{~A}$ cohort mortality table is generally constructed for each birth year representing the actual (or 
anticipated) mortality experience of that specific birth cohort. For example, if we need to project the expected longevity of a 55-year old individual in the year 2000, the 1945 birth cohort table would be appropriate. Cohort life tables take into account expected future mortality improvement, ${ }^{17}$ and thus they provide the basis for calculating how long an individual might be expected to live. When the annuitant cohort mortality table relevant to a given market is available, it may be used to compute money's worth results. In practice, however, many countries have not collected enough data to derive annuitant cohort tables, usually due to insufficient local annuitant experience. In such a circumstance, insurers frequently make use of annuitant cohort tables from other countries having extensive annuity markets, and then transform them to approximate their own national experience. This is the approach adopted in both Singapore and Australia. ${ }^{18}$

Population cohort tables must almost always be derived from period life tables, which are published from time to time by statistical agencies. As with annuitant tables, these must be adjusted to match the year for which annuity pricing data are available. In addition, the tables must be transformed into cohort tables by incorporating projected mortality improvements. Typically these improvements are extrapolations of past mortality improvements recorded between two previous time periods for which life data have been collected. Where available, age-specific projected mortality improvements can also be incorporated.

\footnotetext{
${ }^{15}$ These mortality assumptions are the cumulative probability of living $\mathrm{t}+\mathrm{x}$ for an average person from the annuitant population (based on an annuitant population mortality data) and the cumulative probability of living $\mathrm{t}+\mathrm{x}$ for an average person from the general population (derived from a general population mortality data).

${ }^{16}$ Thus annuity prices for 2000 should use life tables for that same year, if possible, for money's worth valuations.

${ }^{17}$ Period tables describe the mortality rates of individuals at different ages in a given year. On the other hand, cohort tables describe the mortality experience for a given birth cohort as it reaches different ages. Therefore, to value an annuity purchased in 2000 by a 55 -year old, we need a cohort table rather than a period table. For example, the chance that a 55 year old in 2000 will die at age 65 , having survived to that age, will depend on the mortality rate of 65 -year olds ten years from now, not on the mortality of current 65-year olds. See also McCarthy and Mitchell (2000).
} 
Figures 3 and 4 plot cumulative survival probabilities for both males and females aged 65 in Australia and 62 in Singapore. The salient features to be drawn from them is the greater prominence of differential annuitant mortality for both males and females in Australia.

\section{Singapore Money's Worth Calculations}

Singapore's Department of Statistics publishes life tables for the population based on census data approximately every decade. The most recent life tables available were derived from 1990 data, and they are period tables: that is, they provide information about mortality of a cross-section of ages at a point in time and make no allowance for improvements over a cohort's lifetime. To transform these 1990 Singapore tables into a form where they may be used to estimate annuity money's worth, two separate operations must be undertaken: first they 1990 tables must be "aged" to 2000, and then they must be "cohortized".

To explain the process, aging the Singapore population table involves incorporating mortality improvements for each age and gender combination into the most recent period table. We estimate future mortality improvements by extrapolating past improvements implied by mortality changes between the 1990 and 1980 population tables. ${ }^{19}$ Specifically, the mortality improvement over the decade is given by:

$$
\alpha_{x}(1990-1980)=q_{x}(1990) / q_{x}(1980)
$$

where $\alpha_{x}(1990-1980)$ is the mortality improvement rate over the 10 years for each age (represented by $\mathrm{x}$ ) and gender combination. These rates are then applied to the 1990 mortality rated to find the 2000 rates:

$$
q_{x}(2000)=\alpha_{x}(1990-1980) \times q_{x}(1990)
$$

\footnotetext{
${ }^{18}$ For further discussion on annuitant mortality tables see McCarthy and Mitchell (2000) and Mitchell and McCarthy (2000).
} 
where $q_{x}(2000)$ is the period mortality probability for an age $\mathrm{x}$ individual in 2000 .

The resulting period population table for 2000 then must be "cohortized". This process relies on the mortality improvement factors given by (2), but it also requires a separate adjustment for each age cohort. For individuals of age $\mathrm{x}$ in the year 2000, the cohort mortality rate $\left(\hat{q}_{x}\right)$ is defined as follows:

$$
\hat{q}_{x}(2000)=q_{x}(2000) \times\left(1+\frac{-\alpha_{x}}{100}\right)^{0}
$$

where $\alpha_{x}$ now represents the estimated annual mortality improvement for an individual aged $x$. In (4), no change results. But a year later, the expectation of survival will be improved at a rate assumed to be equal to the annual mortality improvement for individuals aged $x+1$. This is given by:

$$
q_{x+1}(2001)=q_{x+1}(2000) \times\left(1+\frac{-\alpha_{x+1}}{100}\right)^{1}
$$

Two years on, the mortality of the cohort is given by

$$
q_{x+2}(2002)=q_{x+2}(2000) \times\left(1+\frac{-\alpha_{\mathrm{x}+2}}{100}\right)^{2}
$$

In general, cohortization of a period table is given by:

$$
\hat{q}_{x+t}(2000+t)=q_{x}(2000) \times\left(1+\frac{-\alpha_{x+t}}{100}\right)^{t}
$$

For money's worth calculations, cumulative survival probabilities are required, given by:

$$
\hat{p}_{x+t}=1-\hat{q}_{x+t}
$$

\footnotetext{
${ }^{19}$ These have been drawn from Swee-Hock (1981) and Tan (1996). Dr Tan kindly supplied us with annualized 1990
} 


$$
{ }_{t} \hat{p}_{x}=\prod_{t=1}^{(\omega-x)} \hat{p}_{x+t}
$$

where $\hat{p}_{x+t}$ is the probability of a person aged $\mathrm{x}$ surviving the year to age $\mathrm{x}+1$, and ${ }_{t} \hat{p}_{x}$ is the cumulative survival probabilities for a person aged $\mathrm{x}$ surviving $\mathrm{t}$ years. These are calculated for each age and gender, for both the general and annuitant populations, on a monthly basis.

\section{Singapore Annuity Quotes}

On reaching age 55, Singaporeans have various options for securing their retirement income. As already discussed, one of these options is to purchase a life annuity from an approved insurance company with the minimum sum of $\$ \operatorname{Sg} 65,000$. Annuities offered in the private market have a deferral period of 7 years until age 62. During this time, benefit payouts are not made so retirees must find alternative sources of income. On reaching the age of 62 , annuity payments commence.

To conduct the money's worth calculation, we base our computations on an annuity design with a guarantee period of 15 years from the first payment. The annuity contract can thus be broken down into three components: a 7-year term deposit (ages 55-62); a 15-year term annuity (ages 62-76); and a life annuity commencing at age 77 . This decomposition allows the annuity quotes actually offered to be converted into estimated quotes on "plain vanilla" individual annuities with the same loadings, and this also makes possible a comparison with annuity offers in other countries.

These calculations also rely on the average monthly payments from the insurance companies for a life annuity financed by the minimum sum, reported in Table $2 .{ }^{20}$ We note that there is considerable variation between annuity issuers in the first-month payouts. For example, a 
nominal life annuity purchased for $\$ 65,000$ by a 55 year-old male pays out between $\$ 468$ and $\$ 600$ per month (as of July 2000). Similar dispersion in annuity payouts have been detected in both the US and UK annuity markets (Mitchell et al., 2000, Finkelstein and Poterba 1999). Table 2 also shows that the payouts for men are higher than those for women for the same annuity products. ${ }^{21}$ This reflects the fact that women on average live longer than do men, and the insurance company therefore expects to pay the annuity out over a longer period.

\section{Table 2 here}

\section{Australian Money's Worth Calculations}

Money's worth values for Australian annuities are derived using a similar approach (Doyle, 2000). As in Singapore, the Australian annuity market is small, limiting the data available with which to derive an Australian annuitant table. For this reason, standard industry practice is to use annuitant tables from the UK and modify them to represent the Australian population. Currently 60 percent of the Individual Male 1980 and Individual Female 1980 (IM80/IF80) ultimate tables are used to benchmark annuitant mortalities in Australia, a standard recommended by the Australian Institute of Actuaries. This adjustment captures future mortality improvements, thereby effectively becoming a cohort mortality table.

Population cohort tables are generated from government Australian Life Tables based on census data. These are adjusted by 100 -year based mortality improvement factors provided by the Australian Government Actuary (1998) to generate population cohort tables. ${ }^{22}$

\section{Australian Annuity Quotes}

\footnotetext{
${ }^{20}$ Details are available at http://www.cpf.gov.sg/cpf_info/home.asp

${ }^{21}$ The interest rate assumed for these valuations in Singapore is 5 percent, which approximates the bond rate, and is close to future expectations.

${ }^{22}$ Further details are provided in Doyle (2000).
} 
Life annuities are offered by about eight life insurers in Australia. The annuity quotes used in the money's worth calculation are the average value of these quotes for December 1999. The annuity type chosen is a nominal individual annuity with no guarantee features, for 60 and 65 year old annuitants. The money's worth results are based on the first year monthly payout from the annuity. The industry average is given in Table 3. The interest rate used for the Australian calculations is 6.96 percent, which is the average market yield on 10-year Australian Government bonds for December 1999 (RBA 2000).

Table 3 here

\section{Money's Worth Results}

To derive money's worth calculations, we rely on data we have collected on the initial payouts for nominal annuities with no guarantee that could be obtained from an initial premium of $\$ 100,000$ for Australia and Singapore (see Table 4). The average Australian payouts for men and women aged 60 and 65 are compared with our estimates of payouts for equivalentlyconfigured annuities in the Singapore context. The main reason for Singapore's lower payouts is that the assumed 5 percent nominal interest rate is lower than the 6.96 percent assumed for Australia.

\section{Table 4 here}

Turning next to money's worth calculations for annuities, results for Singapore appear in Table 5. It is assumed that a retiree purchases a nominal annuity at the age of 55 for the minimum sum of $\$ \operatorname{Sg} 65,000$. Annuity value cumulates over a 7-year deferral period at the nominal riskless rate of 5 percent per annum. In the event that the retiree dies during this period, the initial premium and earnings over the period are returned to the retiree's estate. At 
age 62, the asset value has increased to $\$ S g$ 91,461 which is used to purchase a life annuity with a 15-year guarantee period. These results are to be interpreted as follows: $\$ 1$ of premium spent on purchasing a nominal life annuity by a 55-year old male drawn from the general population in 2000, would generate 93 cents in annuity income (in net present value terms). This represents a loading of 7 percent $(=\$ 1-0.93)$.

\section{Table 5 here}

The money's worth values reported in Table 6 for Australia indicate much more substantial loadings: e.g. almost 20 percent for an annuity sold to a 60 -year old male using population tables. These estimates echo those reported in the US more than a decade ago: Mitchell et al., (2000) report that for a nominal annuity purchased in 1995 in the US and priced using the population mortality for a 65 -year old male, loading accounts for 18.4 cents out of a $\$ 1$ premium. These loadings have declined over time, however, perhaps due to increased market competition (Brown et al, 2000). For the UK, Finkelstein and Poterba (1999) report loadings of about 14 percent in a nominal annuity, using population mortality and the premium for a 65 -year old male in 1998. All of these numbers are much larger than the Singapore loading of only 7 percent.

\section{Table 6 here}

It is worth asking whether the observed difference in loadings between Singapore, on the one hand, and the US and UK, on the other, shrinks when annuitant mortality assumptions are used. The loading for US nominal annuities purchased by 65 -year old males using annuitant tables was only 8 percent (Mitchell et al. , 2000); in the UK, Finkelstein and Poterba (1999) found a 5 percent loading for the annuitant pool only. The corresponding loading in Australia 
for annuitants is 10 percent. In Singapore, the loading is only 6 percent for annuities starting at age 62 .

\section{Evidence of Adverse Selection}

Insurance companies calculate their premiums knowing that annuitants are longer-lived than members of the general population. Given this, it is expected that the EPDV of actuarially fair annuities will be less than unity, based on general population cohort mortality tables. Also the EPDV of annuities based on annuitant cohort mortality tables would be expected to be uniformly higher. The difference between the money's worth of an actuarially fair annuity and the money's worth of a voluntary annuity is our estimate of the extent of adverse selection in the life annuity market.

This translates into different annuitant values for Singapore and Australia, presented in Table 7. The results show a very small estimated difference in Singapore. For instance, for a nominal annuity purchased by a 55-year old male, the cost of adverse selection is apparently tiny: only 0.47 for men and 0.83 percent for women. That is, adverse selection in Singapore apparently accounts for a miniscule fraction of the total life annuity loading. By contrast in Australia the differences are larger, at 8 percentage points for men and over 2 percentage points for women.

\section{Table 7 here}

These results are consistent with the idea that provision of social welfare can adversely affect the efficiency of voluntary annuity markets. That is, the Australian government provides a guaranteed old-age pension sufficient to prevent most elderly from falling into poverty. As a

result, few people see the need to convert private wealth to annuities, and consequently annuity 
penetration is low and adverse selection is high. ${ }^{23}$ In Singapore, by contrast, social assistance outside the CPF is rare. Partly due to this, adverse selection in the pool of annuity purchasers appears low and penetration rates high. It is interesting that this result holds even though the subset of Singaporeans with enough liquid assets to attain the minimum sum threshold at age 55 , and therefore the group able to purchase annuities, is likely to represent the wealthier segment of the population. This group could be anticipated to have greater longevity than the population at large. Only a small number of annuities have thus far been sold in Singapore, but it appears that penetration rates among new retirees is high by international norms.

\section{Discussion}

We have devised and employed a money's worth framework to value life annuities and to measure the extent of adverse selection in Australia and Singapore. Our findings indicate some interesting international patterns. Specifically, administrative loadings are present in both markets, but the degree of selection in the annuity markets differs, with substantially more adverse selection in Australia than in Singapore. We suspect that this arises because of the availability of a generous old-age safety net benefit in Australia that dramatically curtails the risk of old-age poverty. In Singapore no such guarantee is available. In other words, the defined contribution component of the two countries' retirement system is similar, but the extent of annuitization of retirement accumulations appears to respond to the existence of a retirement benefit guarantee. Future work will explore this issue further with data from additional countries.

\footnotetext{
${ }^{23}$ This adverse selection problem is different from the moral hazard described by Smetters (forthcoming) who examines how a minimum benefit guarantee might influence investment portfolio choice in a DC plan.
} 


\section{References}

Asher, Mukul. 1999. "The Pension System in Singapore” World Bank Social Protection Discussion Paper No. 9919. August. Washington, D.C.: World Bank.

Australian Government Actuary. 1999. Australian Life Tables: 1995-97. Australian Government Publishing Service, Canberra.

Bateman, Hazel, Geoffrey Kingston and John Piggott. Forthcoming. Forced Saving: Mandatory Private Retirement Provision. Cambridge University Press.

Bodie, Zvi. 1990. “Pension as Retirement Income Insurance.” Journal of Economic Literature, 28 (March): 28-49.

Brown, Jeffrey R., Olivia S. Mitchell, and James M. Poterba. 2000. “Mortality Risk, Inflation Risk, and Annuity Products.” NBER Working Paper No. W7812.

Brown, Jeffrey R., Olivia S. Mitchell, and James M. Poterba. 1999. “The Role of Real Annuities and Indexed Bonds in an Individual Accounts Retirement Program.” Pension Research Council Working Paper 99-2. Philadelphia, PA: Wharton School.

Brown, Jeffrey R., Olivia S. Mitchell, James Poterba, and Mark Warshawsky. Forthcoming. The Role of Annuity Markets in Financing Retirement. Cambridge, MA: MIT Press.

Central Provident Fund of Singapore. 2000. Minimum Sum Scheme, Annex A1: Table of Monthly Payment Rates for the Minimum Sun Scheme of $\$ 65,000$. Singapore: CPF Board.

Doyle, Suzanne. 2000. "Notes on Interaction of the Pillars: The Net Fiscal Impact of Incentives towards Retirement Income Stream Purchases." Paper presented at the $8^{\text {th }}$ Annual Colloquium of Superannuation Researchers. University of New South Wales: Sydney.

Finkelstein, Amy and James Poterba. 1999. "Selection Effects in the Market for Individual Annuities: New Evidence from the United Kingdom.” NBER Working Paper 7168. 
Friedman, Benjamin and Mark Warshawsky. 1988. "Annuity Prices and Saving Behavior in the United States" in Z. Bodie, J. Shoven and D. Wise, eds, Pensions in the US Economy, University of Chicago Press: Chicago. 53-77.

Friedman, Benjamin and Mark Warshawsky. 1990. "The cost of annuities: Implications for saving behaviour and bequests" Quarterly Journal of Economics, February, Vol. 105, No. 1: $135-154$.

James, Estelle and Dimitri Vittas. 1999. "Annuities Markets in Comparative Perspective”. Paper presented at the World Bank Conference on New Ideas About Old Age Security. Washington, D.C.: World Bank.

Knox, David. 1999. "Investigation of the Australian Annuity Market". Working Paper, Department of Economics, University of Melbourne, Australia.

McCarthy, David and Olivia S. Mitchell. 2000. “Assessing the Impact of Mortality Assumptions on Annuity Valuation: Cross-Country Evidence.” Pension Research Council Working Paper, August. Wharton School, University of Pennsylvania.

McGill, Dan, Kyle N. Brown, John J. Haley, and Sylvester Schieber. 1996. Fundamentals of Private Pensions. $7^{\text {th }}$ Edition. Philadelphia: University of Pennsylvania Press.

Mitchell, Olivia S. and David McCarthy. 2000. "Estimating International Adverse Selection in Annuities.” Pension Research Council Working Paper, September. Wharton School, University of Pennsylvania.

Mitchell, Olivia S., James Poterba, Mark Warshawsky, and Jeffrey Brown. 1999. “New Evidence on the Money's Worth of Individual Annuities", American Economic Review, 89( 5), December: 1299-1-318. 
Murthi, Mamta, J. Michael Orszag, and Peter R. Orszag. 1999. "The Value for Money of Annuities in the U.K.: Theory, Experience, and Policy." Working Paper, Birkbeck College, London.

Palacios, Robert; and Montserrat Pallares-Miralles. 2000. "International Patterns of Pension Provision.” World Bank Social Protection Discussion Paper No. 9. . April. Washington, D.C.: World Bank.

Plan for Life Research. 2000a. The Immediate Annuity: Product and Rate Report. Issue 24, August, Victoria, Australia.

Plan for Life Research. 2000b. The Allocated Pension Report. Issue 32, August, Victoria, Australia.

Reserve Bank of Australia (RBA). 2000. Bulletin, February. Australian Government Publishing Service, Canberra.

Rice Kachor. 2000. Annuity and Pension League Tables. February. Sydney, Australia.

Rice Kachor. 1998, Annuity and Pension Analysis, March. Rice Kachor: Sydney, Australia.

Sherris, Michael. 1995. "The Valuation of Option Features in Retirement Benefits." Journal of Risk and Insurance. 62(3): 509-535.

Smetters, Kent. Forthcoming. “The Design and Cost of Pension Guarantees.” In Public Policies and Private Pensions. Eds. William Gale, John Shoven, and Mark Warshawsky. The Brookings Institution: Washington, DC.

Swee-Hock, S. 1981. Demographic trends in Singapore. Census Monograph no.1, Department of Statistics. Singapore.

Tan, Khye Chong. 1996. "Recent Mortality Trends in Singapore.” Quarterly Journal Institute of Actuaries of Australia. September: 59-71. 
Warshawsky, Mark. 1988. "Private Annuity Markets in the United States". Journal of Risk and Insurance. 55 (3) September. 
T. 1: Trends in Annuity Sales in Singapore, 1990-1999

\begin{tabular}{lccccccccccc}
\hline & $\mathbf{1 9 9 0}$ & $\mathbf{1 9 9 1}$ & $\mathbf{1 9 9 2}$ & $\mathbf{1 9 9 3}$ & $\mathbf{1 9 9 4}$ & $\mathbf{1 9 9 5}$ & $\mathbf{1 9 9 6}$ & $\mathbf{1 9 9 7}$ & $\mathbf{1 9 9 8}$ & $\mathbf{1 9 9 9}$ \\
$\begin{array}{l}\text { Annuities } \\
\text { Sold }\end{array}$ & 380 & 720 & 1350 & 1510 & 1690 & 1970 & 2340 & 2550 & 2030 & 3200 \\
\begin{tabular}{l} 
\% increase \\
\hline
\end{tabular} & & 89.5 & 84.7 & 13.5 & 11.9 & 16.6 & 18.8 & 9.0 & -20.9 & 57.6 \\
\hline
\end{tabular}

Source: Personal Communication, NTUC Office, Singapore July 2000.

T. 2: Annual Nominal Life Annuity Payouts for 55-year old Men and Women in Singapore $(\mathrm{Sg} \$)$

\begin{tabular}{lcc}
\hline & $\begin{array}{c}\text { Male } \\
\text { \$ per month }\end{array}$ & $\begin{array}{c}\text { Female } \\
\text { \$ per month }\end{array}$ \\
AIA & $\$ 468.00$ & $\$ 444.60$ \\
GE life & $\$ 585$ & $\$ 555$ \\
ICS & $\$ 575$ & $\$ 510$ \\
Keppel & $\$ 551$ & $\$ 504$ \\
UOB life & $\$ 600$ & $\$ 555$ \\
Average & $\$ 555$ & $\$ \mathbf{5 1 9}$ \\
\hline
\end{tabular}

Note: Annual payouts from a flat nominal annuity purchased at 55 with payments starting at age 62 and a 15-year guarantee period or similar. Premium is government set minimum sum of $\mathrm{Sg} \$ 65,000$. Source: Central Provident Fund (July 2000).

T. 3: Annual Nominal Life Annuity Payouts for 60 and 65-year old Men and Women in Australia (A\$)

\begin{tabular}{lcccc}
\hline & \multicolumn{2}{c}{ Male } & \multicolumn{2}{c}{ Female } \\
Average & Age 60 & Age 65 & Age 60 & Age 65 \\
\hline N8,172 & $\$ \mathbf{\$ 9 , 1 0 3}$ & $\$ \mathbf{\$ 7 , 5 9 5}$ & $\mathbf{\$ 8 , 2 9 1}$ \\
\hline
\end{tabular}

Note. Annual payouts from a flat nominal annuity purchased at 65 with immediate payments. Premium is A \$100,000. Source: Rice Kachor (December 2000) 
T. 4: Annual Life Annuity Payouts for Singapore and Australia Computed at $\$ 100,000$ Premium

\section{Australia Singapore}

$\begin{array}{lll}\text { Male } & \$ 8,638 & \$ 7,977 \\ \text { Female } & \$ 7,943 & \$ 7,090\end{array}$

Note: Assumed nominal interest rate 5 percent in Singapore and 6.96 percent in Australia, consistent with historical trend. Values given in local currencies. Source: Authors' calculations; see text.

T. 5: Money's Worth of Average Singaporean Life Annuity Purchased at Age $62(\%)$

$\begin{array}{cc}\text { Annuitant } & \text { Population } \\ \text { mortality basis } & \text { mortality basis }\end{array}$

$\begin{array}{lrr}\text { Male } & 93.91 & 93.44 \\ \text { Female } & 95.44 & 96.27\end{array}$

Note: Population mortality tables used; assumed nominal interest rate 5 percent in Singapore consistent with historical trend, Source: Authors' calculations; see text.

T. 6: Average Money's Worth of Australian Life Annuity Purchased at Age 60 or $65(\%)$

\begin{tabular}{lcc} 
& $\begin{array}{l}\text { Annuitant } \\
\text { Mortality basis }\end{array}$ & $\begin{array}{c}\text { Population } \\
\text { Mortality basis }\end{array}$ \\
Male 60 & 88.89 & 80.97 \\
Male 65 & 90.40 & 83.73 \\
Female 60 & 90.26 & 86.65 \\
Female 65 & 89.38 & 87.04 \\
\hline
\end{tabular}

Note: Population mortality tables used; assumed nominal interest rate $6.96 \%$ in Australia consistent with historical trend. Source: Authors' calculations; see text.

T. 7: Measured Adverse Selection in Life Annuity Markets of Singapore and Australia (\%)

$\begin{array}{lcc} & \text { Singapore } & \text { Australia } \\ \text { Male } & 0.47 & 7.92 \\ \text { Female } & 0.83 & 2.34 \\ \text { Note: Assumed nominal interest rate 6.96 percent in Australia and 5 percent in } \\ \begin{array}{l}\text { Singapore. Comparison relies on comparison of money's worth with annuitant and } \\ \text { mortality tables. Source: Authors' calculations; see text. }\end{array}\end{array}$


Figure 1: Funds Under Management in the Australian Income Stream Market (\%)

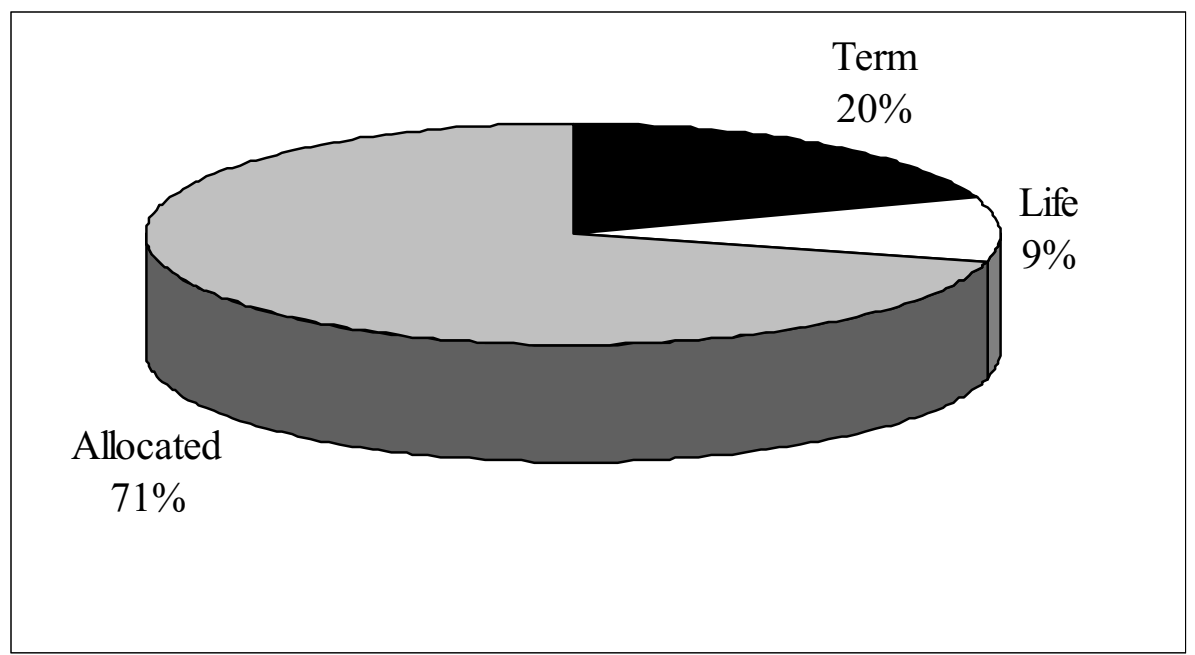

Source: Plan for Life Research (2000a); (June 2000)

Figure 2: Immediate Annuity Sales in Australia (\$A million)

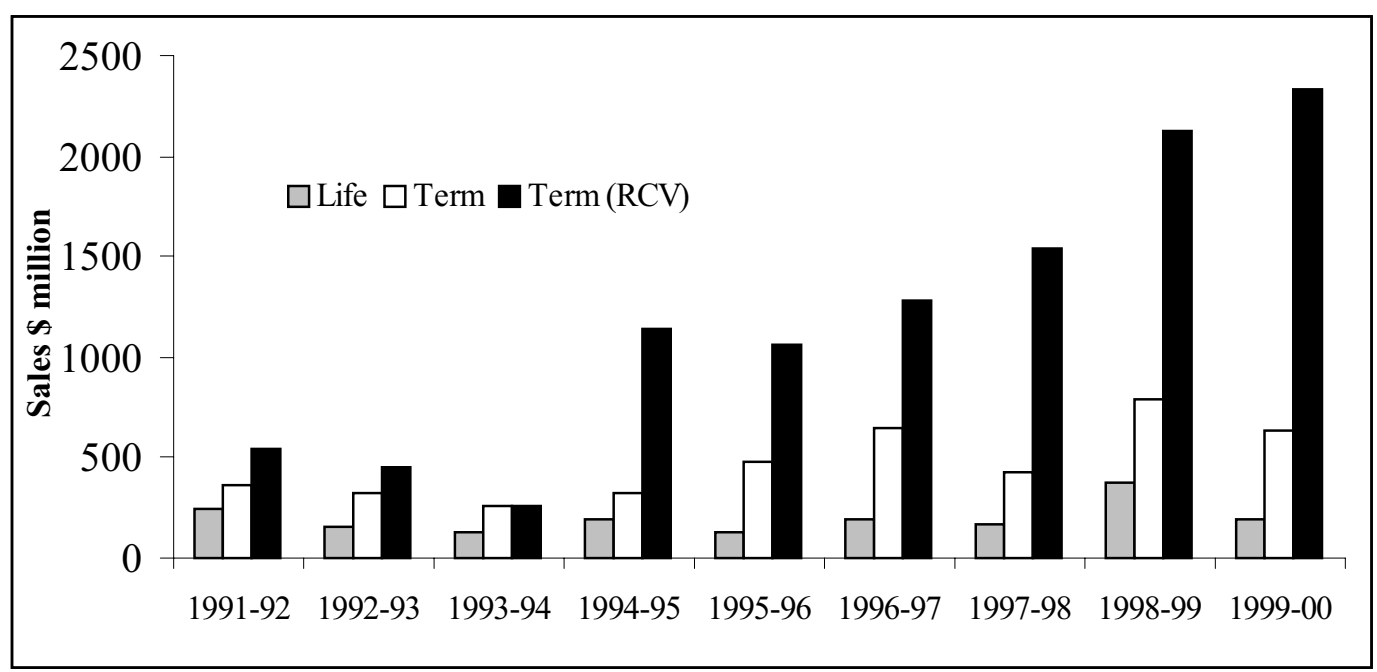

Source: Plan for Life Research (2000a); (July 2000) 
Figure 3a: Cumulative cohort survival probability - general and annuitant populations Australian males, 1999

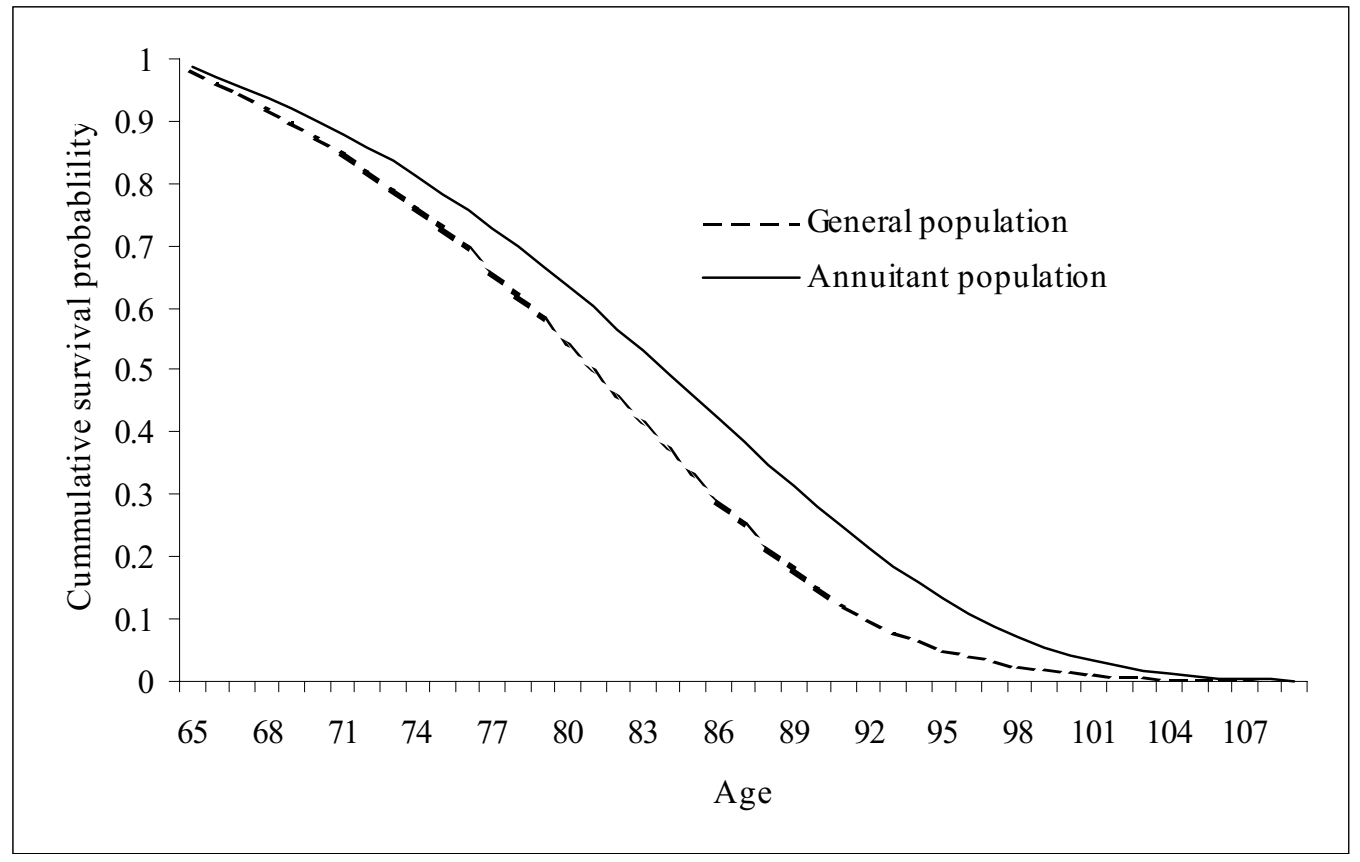

Figure 3b: Cumulative cohort survival probability - general and annuitant populations Australian females, 1999

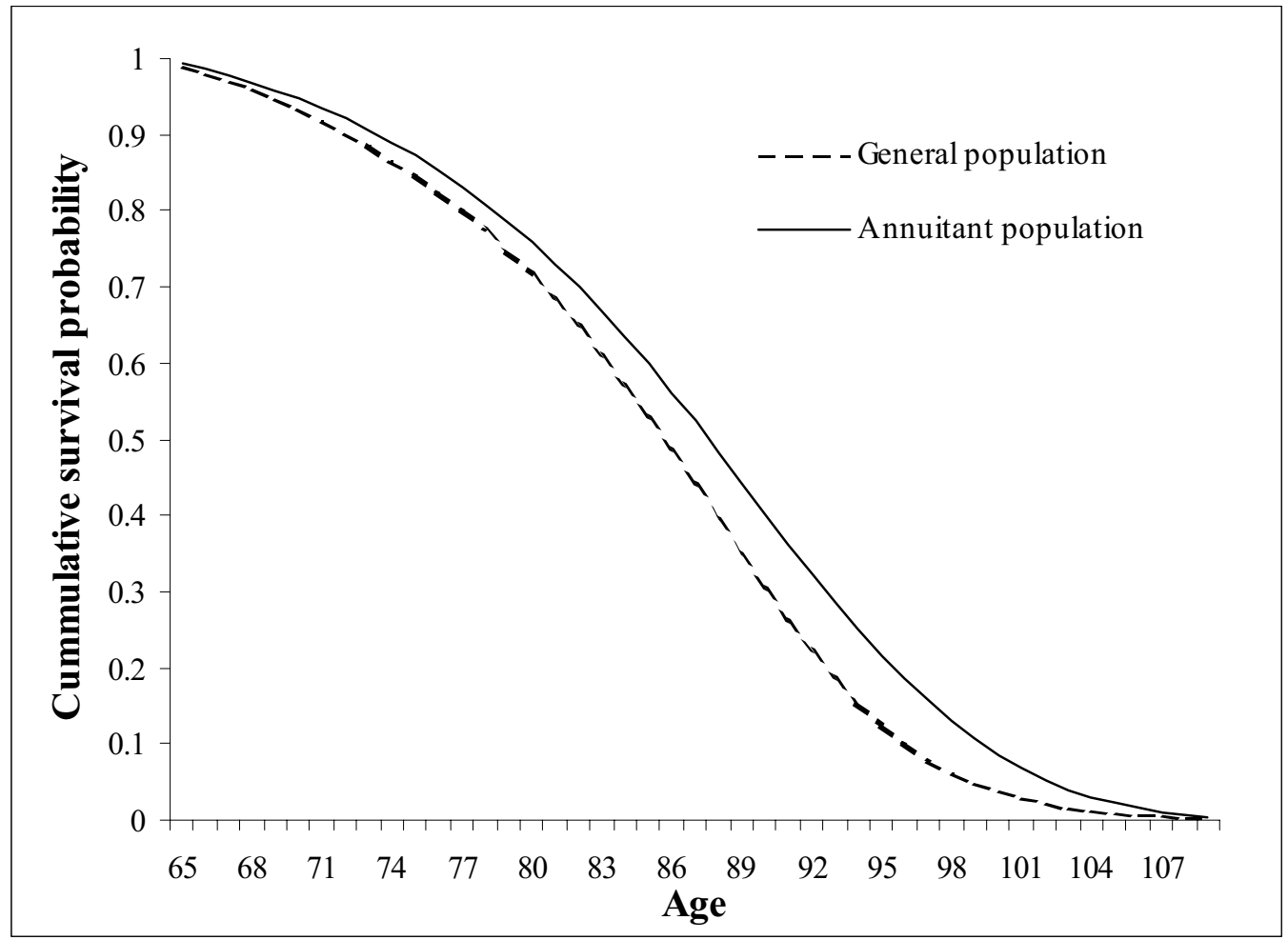


Figure 4a: Cumulative cohort survival probability - general and annuitant populations Singaporean males, 1999

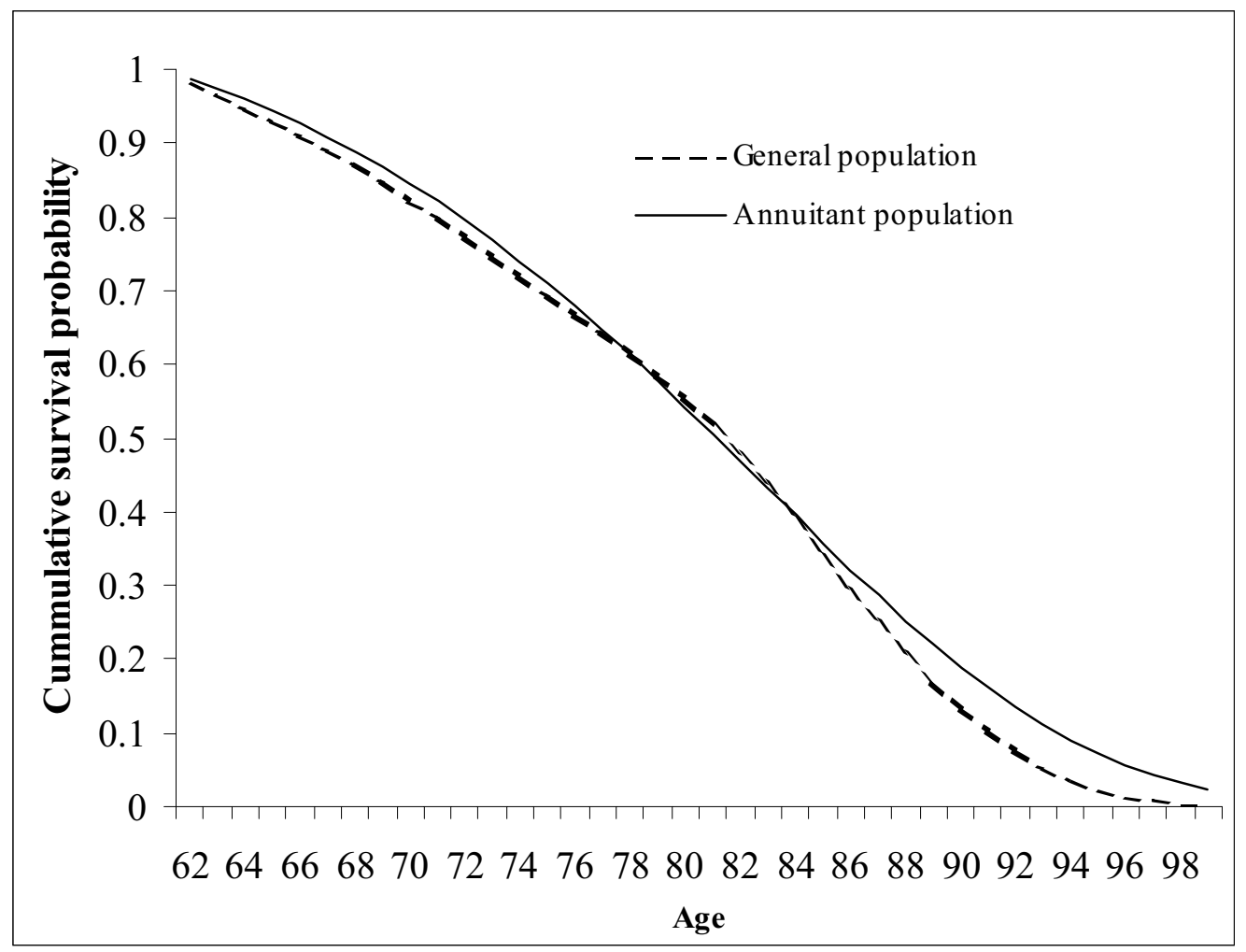

Figure 4b: Cumulative cohort survival probability - general and annuitant populations Singaporean females, 1999

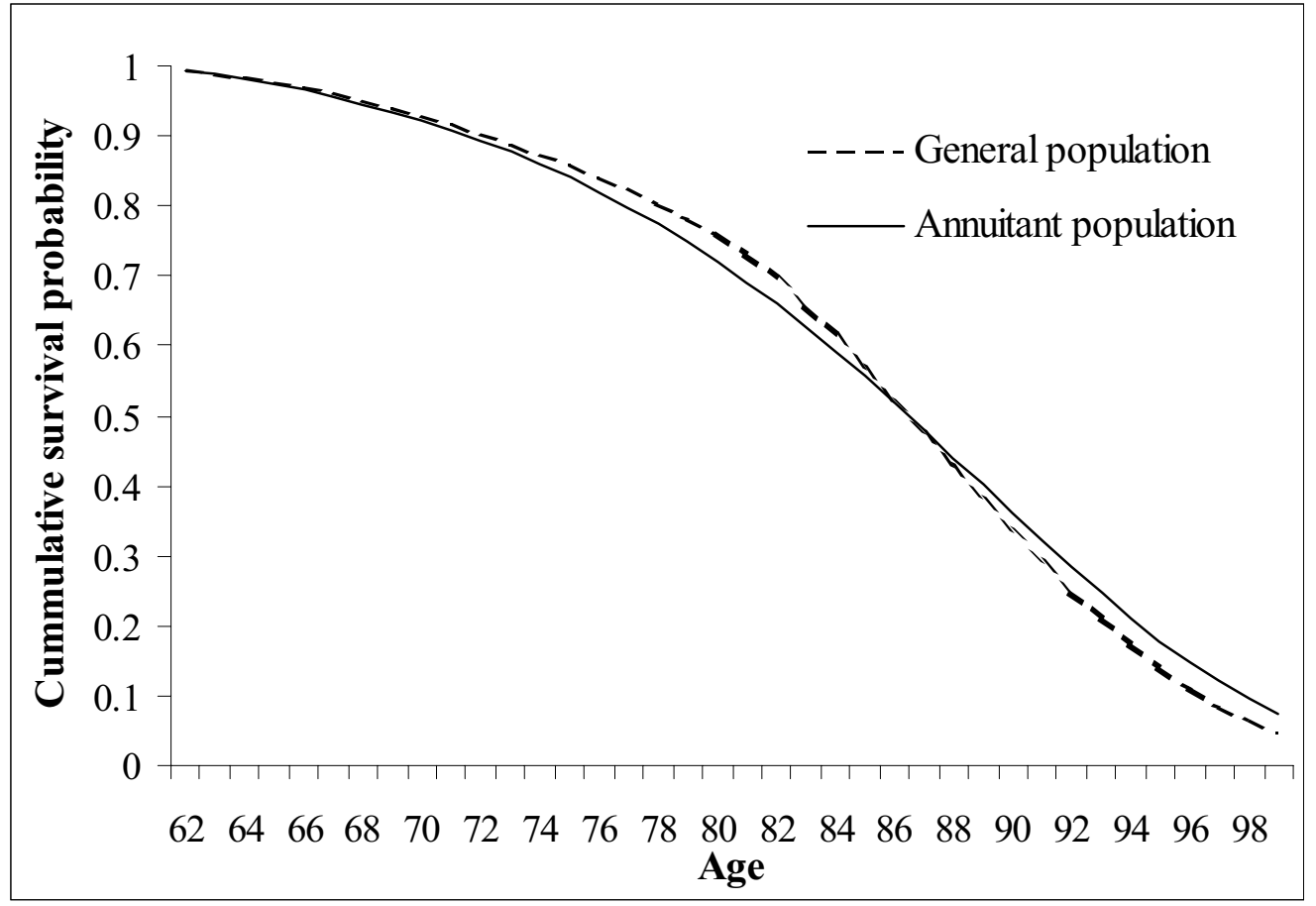

